\title{
The effects of 8-week aerobic training on body weight among sedentary females
}

\author{
Samet AKTAS¹, Gamze OZDIL², Ozlem BAGIS ${ }^{\text {, Faruk GUVEN³ }}$ \\ ${ }^{1}$ Faculty of SportScience, SelcukUniversity, Konya, Turkey. \\ ${ }^{2}$ School of Physical Education and Sports, Gaziantep University, Gaziantep, Turkey. \\ ${ }^{3}$ School of Physical Education and Sports, Kilis 7 AralikUniversity, Kilis, Turkey. \\ This research was presented as a poster at $3^{\text {rd }}$ International Sport Sciences, Tourism and Recreation Student Congress on May 27-29, 2016. \\ AddressCorrespondenceto S. Aktaş. sametaktas@selcuk.edu.tr
}

\begin{abstract}
In this study, it was intended to see how a-8 week aerobic traininig applications affected weight loss and body composition among the sedentary females. A training programme of aerobic training (walking and cycling) with mild abdominal, arm and hip exercises was carried out for 60 minutes in 3 days of a week (Monday, Wednesday and Friday) during 8 weeks. Age, height and weight values regarding ones participated in the study were given as mean and standart deviation. Paired-Sample $\mathrm{T}$ test was used to compare pre and post test values of the group participated in the study. The statistical significance level was regarded as 0.05 . The participants had age average of $23.27 \pm 5.04$, body weight average of $62.99 \pm 9.49$, height average of $163.00 \pm 3.95$. Statistically significant differences were not observed in weight, arm, shoulder, breast, leg and hip values concerning the participiants $(p<0.05)$. Differences were observed in the pre and post test values. There was not statistically significant differences when comparing the pre and post tests of the waist measurements. As a result; a 8-week aerobic training application affected positively weight loss and body composition among the sedentary females.
\end{abstract}

Keywords: Aerobic, sedentary, weight loss, female.

\section{INTRODUCTION}

Each healthy individual is capable of moving. Furthermore, the situation for developing this capability is highly different. When human body is examined, it is seemed to consist of muscle, fat and bone tissue having different rates and intervals in accordance with gender (1).

Within growth, development and ageing processes starting with birth, due to changes in any organism, many characteristics such as strength, endurance and life quality show tendency for retardation (6). Unsedentary life is possibly one of the greatest harmful diseases among persons in the modern world (8).

Nowadays a sedentary lifestyle causes deterioration in energy balance, that's why, obesity may occur. Obesity is characterised with the redundancy of fat rate and the rise of endomorphy rate. Especially when body weight exceeds normal limitations, decreases may be seen in physical work capacity as well as many serious health problems $(5,9)$.
A sedentary lifestyle leads to various health problems for each age group. In particular, several chronic diseases which occur following a certain age, bring lots of problems for middle age and over it. In order to save from all these negative conditions, keep organism alive and healthy; activities such as sport, fitness, aerobics, jogging, etc. have been increasingly important for a healthy life $(4,10,15,16)$.

Females have tendencies to put on weight more than males as percentage of body weight. Body fat increases with the effects of estrogen in female individuals at the beginning of puberty. The increasing body fat rate is accompanied by a number of cases including pregnancy and menopause (20).

To protect body composition, in addition to enough and balanced nutrition, regular exercise habits and sustainable lifestyles are needed. Except for limitations of normal body weight, both weakness and obesity show great differences in developing and developed countries. While weakness is a substantial health problem in countries devoid of food, obesity is on the first order 
in developed or developing countries as a health problem. Obesity is a public health problem and also an economic problem at global dimensions. Its prevalance rate increases all around the world and affects females more (3).

According to health risks, the most effective exercise types are ones such as jogging, running, trekking, cycling, rowing, swimming which increase aerobic capacity. High efficiency can be achieved by aerobic exercises in resolving health problems especially such as obesity, cardiovascular diseases and bone troubles (21). Regular and enough exercises help persons achieve the desired aim and improve training effects. The enough level is based on exercise type, volume, period and frequency. Considering these principles, any exercise program leads to effective results even in elderly people or people not doing exercise before $(12,17)$. In this study; it was aimed to analyze the effects of 8-week aerobic training program on body composition in sedentary females.

\section{MATERIALS \& METHOD}

The research was done at the fitness hall in Selçuk University. Fifteen sedentary females (age = $23.27 \pm 5.04$ years, Weight $=62.99 \pm 9.49 \mathrm{~kg}$, height $163.00 \pm 3.95 \mathrm{~cm}$ ) were included in the study. Each training session was 60 minutes for 3 times (Monday, Wednesday, Friday) in a week during a 8week training program. aerobic trials (jogging and cycling) and a training program of slight abdomen, arm and hip exercises, movements were performed. The body circumference estimations of the females participated in the study were measured by a tape rule, the measurements were recorded as pre-test and post-test. Age (years), height and body weight $(0.1 \mathrm{~kg}$, sensitivity to $0.1 \mathrm{~cm})$, shoulder circumference (sensitivity to $0.1 \mathrm{~cm}$ ), chest circumference (sensitivity to $0.1 \mathrm{~cm}$ ), abdomen circumference (sensitivity to $0.1 \mathrm{~cm}$ ), biceps circumference (biceps during extension) (sensitivity to $0.1 \mathrm{~cm}$ ), hip circumference (sensitivity to $0.1 \mathrm{~cm}$ ) were measured, data were recorded.

Data analysis: In analysis of data, SPSS 21(SPSS INC. USA) computer program was used. Age, height and weight values of the research participants were given as averages and standard deviations, and in the comparison of pre-test and post-test values Paired- Sample T test was used. The statistical significance level was regarded to be 0.05 .

\section{RESULTS}

The research participants' age average was $23.27 \pm 5.04$ years, body weight average was $62.99 \pm$ $9.49 \mathrm{~kg}$, height average $163.00 \pm 3.95 \mathrm{~cm}$ (Table 1).

Table 1.Age, weight and height values regarding participants.

\begin{tabular}{llc} 
& $\mathrm{N}$ & Mean \pm SD \\
\hline Age (years) & 15 & $23.27 \pm 5.04$ \\
Weight $(\mathrm{kg})$ & 15 & $62.99 \pm 9.49$ \\
Height $(\mathrm{cm})$ & 15 & $163.00 \pm 3.95$ \\
\hline
\end{tabular}

Table 2. Comparison of pre-test and post-test values regarding participants.

\begin{tabular}{lllcccc}
\hline & & $\mathrm{N}$ & Mean $\pm \mathrm{SD}$ & $\mathrm{df}$ & $\mathrm{t}$ & $\mathrm{p}$ \\
\hline Weight $(\mathrm{kg})$ & Pre test & 15 & $62.99 \pm 9.49$ & \multirow{2}{*}{14} & 26.021 & $0.000^{*}$ \\
& Post test & 15 & $60.80 \pm 9.44$ & & & \\
Arm $(\mathrm{cm})$ & Pre test & 15 & $28.50 \pm 3.78$ & 14 & 7.750 & $0.000^{*}$ \\
& Post test & 15 & $27.47 \pm 3.64$ & & & \\
Shoulder (cm) & Pre test & 15 & $103.04 \pm 6.96$ & 14 & 6.263 & $0.000^{*}$ \\
& Post test & 15 & $100.50 \pm 6.05$ & & & \\
Chest $(\mathrm{cm})$ & Pre test & 15 & $91.93 \pm 7.96$ & 14 & 8.944 & $0.000^{*}$ \\
& Post test & 15 & $89.93 \pm 7.89$ & & & \\
Waist $(\mathrm{cm})$ & Pre test & 15 & $82.17 \pm 9.58$ & 14 & 1.448 & 0.170 \\
& Post test & 15 & $81.23 \pm 9.67$ & & & \\
Leg $(\mathrm{cm})$ & Pre test & 15 & $55.87 \pm 6.01$ & 14 & 14.734 & $0.000^{*}$ \\
& Post test & 15 & $53.90 \pm 5.98$ & & & \\
Hip $(\mathrm{cm})$ & Pre test & 15 & $100.63 \pm 7.89$ & 14 & 3.579 & $0.003^{*}$ \\
& Post test & 15 & $99.19 \pm 8.54$ & & & \\
\hline${ }^{*} \mathrm{p}<0.05$ & & & & & &
\end{tabular}

At Table 1, the comparisons between the pretest and post-test measurements of weight, arm, shoulder, chest, waist, leg and hip in the participants were given. In accordance with this one, there were statistically significant differences in weight, arm, shoulder, chest, waist, leg and hip estimations $(\mathrm{p}<0.05)$. In the pre-test and post-test comparisons of waist values, there was not any statistically significant difference.

\section{DISCUSSION}

Recently many fitness halls and sport centers have organized healthy life programs, presented exercise plans appropriate for persons' needs, interests, periods. Many researches have been done about innovations by modern life and technology. Within the research, the results support information mentioned in the literature when examined measurements of body weight, arm, shoulder, chest, waist, leg and hip circumferences. As there are significant $(p<0.05)$ differences in body weight, arm, shoulder, chest, leg and hip circumferences, there is no significant difference in estimations of waist circumference. 
In literature, Çakaloğlu \& Karacan informed that there were significant differences in body mass indexes like in our study due to aerobic trainings for 30 minutes in 3 days during 8 weeks (7).

Amono Kanda and Maritai applied a training program in 18 obese subjects for 30 minutes, 3 days in a week during 3 months and stated that there was a significant difference in fat percentage rate before and after trainings. Our study complied with this research (2). In another study by İmamoğlu et al. 45 sedentary females having an average age of 36.11 \pm 1.04 years, an average body weight $70.83 \pm 1.67 \mathrm{~kg}$ did exercises for $60 \mathrm{~min}$ during 3 days in a week providing that they had heart rate of 130-140 rate/min, and they had decreases in their body weight and fat percentage rate (11). In a similar way to our study, Szmedra et al. performed treadmill exercises in middle-aged females in their research. They claimed that their body mass index reduced as a result of trainings (18).

Wang et al. classified 30 overweight sedentary females aged between 45-59 into 2 groups including experimental and control groups. With the aim of analyzing intensity of maximal fat oxidation (FatMax) in sedentary females, they applied physical fitness in the experimental group for 10 weeks, therefore, there was a significant $(p<0.05)$ difference in maximal fat oxidation of the experimental group as there was not any significant difference in the control group (19).

Nindl et al. (2000) carried out an exercise program of resistance and aerobic combination in 31 healthy females for 5 days in a week during 6 months and recorded a decrease of $2.2 \%$ in their body mass as a result of trainings (13). Polat (2000) suggested that there was a significant difference in body fat rate as a result of an exercise program performed during 8 weeks, when the significant reduction in fat percentage was evaluated in the light of information within the literature, our study was parallel with thes ones (14).

In conclusion, an aerobic training program applied for 8 weeks positively affected weight loss in sedentary females and depending on this, body composition in females. Based on this result, when considering the effects of aerobic training programs on weight loss in fitness halls, these are predicted to be included among the first preferences. Here, it can be considered to plan aerobic training programs which provide weight loss, positively affect body composition and improve life quality in females, for a long term.

\section{REFERENCES}

1. Akgün N. Egzersiz ve Spor Fizyolojisi. İzmir: Ege Üniversitesi Basımevi, 1996.

2. Amano M, Kanda T, Ue H, Moritani T. Exercise training and autonomic nervous system activity in obese individuals. Medicine and Science in Sports and Exercise, 2001; 33: 12871291.

3. Björntorp P. International Textbook of Obesity. John Wiley \& Sons Ltd, 2001.

4. Bompa T. Antrenman Kuramı ve Yöntemi. Ankara: Kültür Ofset, 1998.

5. Carter JL, Heath BH. Somatotyping: development and applications. Cambridge University Press, 1990

6. Çolakoğlu FF. 8 Haftalık Koş Yürü Egzersizinin Sedanter Orta Yaşlı Obez Bayanlarda Fizyolojik, Motorik ve Somatotip Değerleri Üzerine Etkisi. Gazi Üniversitesi Gazi Eğitim Fakültesi Dergisi, 2003; 3 .

7. Çolakoğlu FF, Karacan S. Genç bayanlar ile orta yaş bayanlarda aerobik egzersizin bazı fizyolojik parametrelere etkisi. Kastamonu Eğitim Dergisi, 2006; 14: 277-284.

8. Dönmez G, Aydos L. Kalistenik çalışmaların orta yaşlı sedanter bayanların fizyolojik ve fiziksel parametreleri üzerine etkisi. Gazi Beden Eğitimi ve Spor Bilimleri Dergisi,2000; 5: 17-25.

9. Erkan N. Yaşam boyu spor. Bağırgan Yayımevi, Ankara: 95, 1998.

10. Ersoy G. Sağlıklı Yaşam, Spor ve Beslenme. Damla Matbaacilık, Ankara, 1995.

11. Imamoglu O, Akyol P, Bayram L. Sedanter Bayanlarda 3 Aylik Egzersizin Fiziksel Uygunluk, Vucut Kompozisyonu ve Bazi Kan Parametreleri Uzerine Etkisi, 7. Uluslararasi Spor Bilimleri Kongresi, 27-29, 2002.

12. Kuter Ö. Elit Basketbolcularda Kuvvet Antrenmanlarının Vücut kompozisyonu Üzerine Etkisi. Spor bilimleri Dergisi, 1991; 2: 9-15.

13. Nindl BC, Harman EA, Marx JO, Gotshalk LA, Frykman PN, Lammi E, Palmer C, Kraemer WJ. Regional body composition changes in women after 6 months of periodized physical training. Journal of Applied Physiology, 2000; 88: 2251-2259.

14. Polat Y. Çabuk Kuvvet ve Sprint Antrenmanlarının Reaksiyon Zamanına Etkisi. Yüksek Lisans Tezi Konya: Selçuk Üniversitesi, 2000.

15. Saygin O, Dükancı Y. The examination of the relationship between health-related physical fitness and the density of physical activity among girls. International Journal of Human Sciences, 2009; 6: 320-329.

16. Schlegel TR. The Training Effects of a Vigorous Aerobic Exercise Program Upon the Composition, Neuromuscular Endurance, Flexibility, and Cardiorespiratory Capacity of 24 Males Aged 49 to 69 Years as Measured Annually Over Three Years. Microform Publication, University of Oregon, Eugene,Ore. , 1986.

17. Sevim Y, Önder O, Gökdemir K. Çabuk kuvvete yönelik istasyon çalışmasının 18-19 yaş grubu erkek öğrencilerin bazı kondüsyonel özellikleri üzerine etkileri. Gazi Beden Eğitimi ve Spor Bilimleri Dergisi, 1996; 1: 18-24. 
18. Szmedra L, Lemura L, Shearn W. Exercise tolerance, body composition and blood lipids in obese African-American women following short-term training. The Journal of Sports Medicine and Physical Fitness,1998; 38: 59-65.

19. Wang J, Tan S, Cao L. Exercise training at the maximal fat oxidation intensity improved health-related physical fitness in overweight middle-aged women. Journal of Exercise Science \& Fitness, 2015; 13: 111-116.
20. Wing RR. Changing Diet and Exercise Behaviors in Individuals at Risk for Weight-Gain. Obesity Research, 1995; 3: 277-S282.

21. Zorba E. Herkes için spor ve Fiziksel Uygunluk. Neyir Matbaası, Ankara, 1999 